\title{
Correction to: Oxidative stress enhances the expression of IL-33 in human airway epithelial cells
}

Hiroyuki Aizawa', Akira Koarai", Yutaka Shishikura', Satoru Yanagisawa', Mutsuo Yamaya², Hisatoshi Sugiura', Tadahisa Numakura', Mitsuhiro Yamada'1, Tomohiro Ichikawa'', Naoya Fujino'1, Masafumi Noda', Yoshinori Okada ${ }^{3}$ and Masakazu Ichinose ${ }^{1}$

\section{Correction}

Figure 2 of this original publication was incorrectly formatted. The updated Fig. 2 is published in this correction article [1].

\begin{abstract}
Author details
${ }^{1}$ Department of Respiratory Medicine, Tohoku University Graduate School of Medicine, 1-1 Seiryo-machi, Aoba-ku, Sendai 980-8574, Japan. ${ }^{2}$ Department of Advanced Preventive Medicine for Infectious Disease, Tohoku University Graduate School of Medicine, 1-1 Seiryo-machi, Aoba-ku, Sendai 980-8575, Japan. ${ }^{3}$ Department of Thoracic Surgery, Institute of Development, Aging and Cancer, Tohoku University, 4-1 Seiryo-machi, Aoba-ku, Sendai 980-8575, Japan.
\end{abstract}

Received: 24 April 2018 Accepted: 29 May 2018

Published online: 12 June 2018

\section{Reference}

1. Aizawa $\mathrm{H}$, et al. Oxidative stress enhances the expression of IL-33 in human airway epithelial cells. Respir Res. 2018;19:52. https://doi.org/10.1186/s12931018-0752-9.

\footnotetext{
*Correspondence: koarai@rm.med.tohoku.ac.jp

${ }^{1}$ Department of Respiratory Medicine, Tohoku University Graduate School of

Medicine, 1-1 Seiryo-machi, Aoba-ku, Sendai 980-8574, Japan

Full list of author information is available at the end of the article
}

(c) The Author(s). 2018 Open Access This article is distributed under the terms of the Creative Commons Attribution 4.0 International License (http://creativecommons.org/licenses/by/4.0/), which permits unrestricted use, distribution, and reproduction in any medium, provided you give appropriate credit to the original author(s) and the source, provide a link to the Creative Commons license, and indicate if changes were made. The Creative Commons Public Domain Dedication waiver (http://creativecommons.org/publicdomain/zero/1.0/) applies to the data made available in this article, unless otherwise stated. 
a

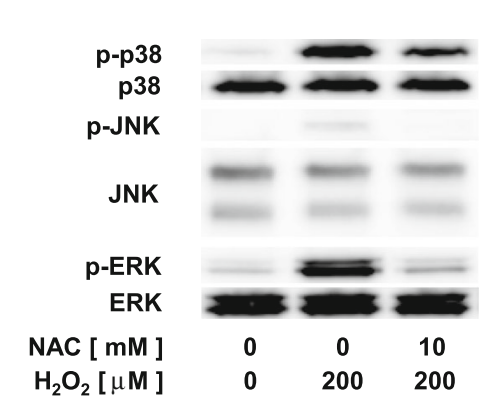

C

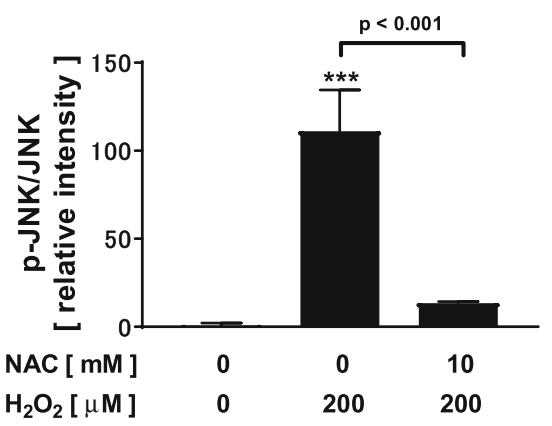

e

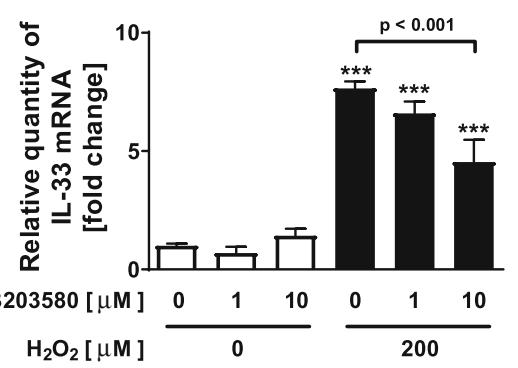

b

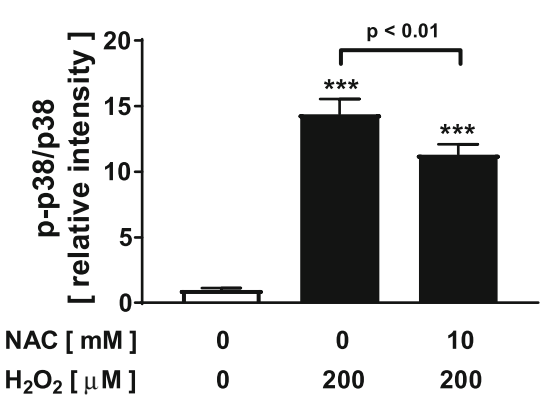

d
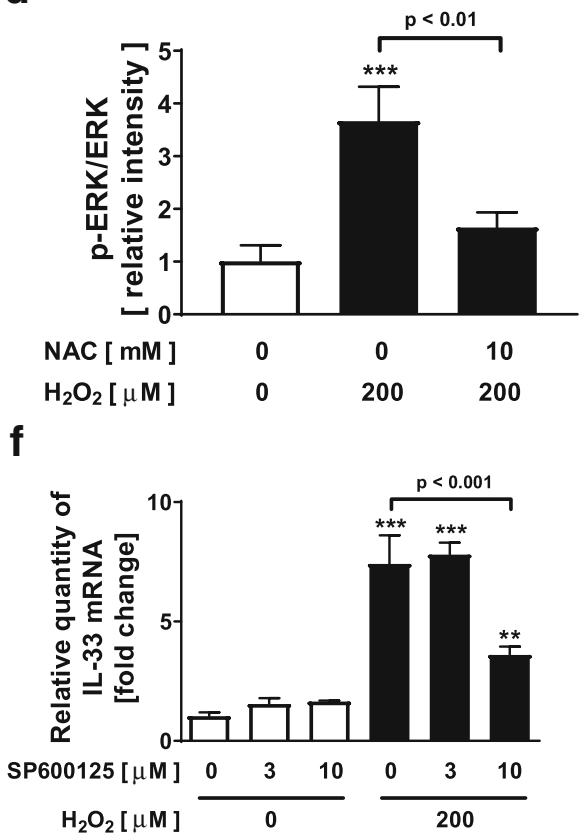

g

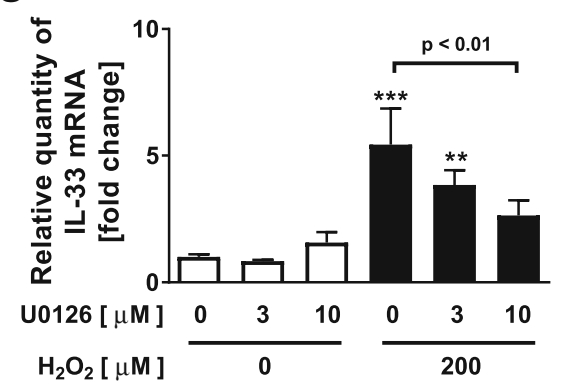

